\title{
Origins of Saline Minerals in Lower Permian Alkaline Lacustrine Deposits in Mahu Sag, Northwestern Junggar Basin: Impact on Hydrocarbon Accumulation
}

\author{
YUANYUAN ZHANG ${ }^{1}$, WeI LI ${ }^{1}$ \\ ${ }^{1}$ Key Laboratory of Orogenic Belts and Crustal Evolution, \\ School of Earth and Space Science, Peking University, \\ Beijing 100871, China
}

Mahu sag, northwestern Junggar basin, is one of the most prolific oil-gas sags in North Xinjiang, China. Lower Permian Fengcheng formation is considered to be the oldest alkaline lacustrine strata, which provides the resource foundation for the formation of hundreds-of-miles oil province. Saline minerals in the Lower Permian Fengcheng Formation play a significant role in the recovery of palaeoenvironment, emplacement of tight oil and enrichment of organic matters, but have been relatively poorly understood. Based on detailed analyses from optical microscopy, SEM, electronic probe, Raman spectroscopy, XRD and fluid inclusions, saline minerals including mainly sodium carbonates and sodium silicates were identified, and their paragenetic sequence have been well demonstrated. The major sodium carbonates include wegscheiderite, shortite, eitelite, northupite and burbankite and the sodium silicates are reedmergnerite, searlesite, leucosphenite and aegirine. Primary aqueous fluid inclusions in eitelite, shortite and reedmergnerite show homogenization temperatures ranging from $70{ }^{\circ} \mathrm{C}$ to $80{ }^{\circ} \mathrm{C}$, $80{ }^{\circ} \mathrm{C}$ to $90{ }^{\circ} \mathrm{C}$ and $95{ }^{\circ} \mathrm{C}$ to $110{ }^{\circ} \mathrm{C}$ respectively. All the saline minerals are investigated to have a mesodiagenetic origin. Eitelite, shortite, northupite and wegscheiderite formed successively through recrystallization and replacement from synsedimentary carbonate muds. Subsequently searlesite and reedmergnerite formed as transformation products of volcanic ashes. The composite sodium-silicates veins finally crystalized from hydrothermal fluid. Primary heavy oil fluid inclusions are present in eitelite, northupite, reedmergnerite and shortite, and bitumen is also found to fill crystal growth planes in eitelite. Therefore, the emplacement of hydrocarbon occurred simultaneously with the dissolution, replacement, transformation and recrystallization of most saline minerals and consequently, diagenesis of alkaline sediments from Fengcheng Formation has not been inhibited by hydrocarbon emplacement. 